\title{
Ammonia affects performance and thermoregulation of male broiler chickens ${ }^{1}$
}

\author{
Shlomo YAHAV* \\ Institute of Animal Science, Agricultural Research Organization, The Volcani Center, PO Box 6, \\ Bet Dagan 50250, Israel
}

(Received 9 February 2004; accepted 12 July 2004)

\begin{abstract}
The effects of various atmospheric ammonia concentrations $(X \pm$ S.E.; $16 \pm 2 ; 28 \pm 3$; $39 \pm 4$; and $54 \pm 5 \mathrm{ppm})$ at high ambient temperature $\left(\mathrm{T}_{\mathrm{a}}=32^{\circ} \mathrm{C}\right)$ and relative humidity $(\mathrm{rh}=60$ $65 \%)$ on the performance and thermoregulation of male broiler chickens were studied. Body weight declined significantly and proportionally with increasing ammonia concentration in the air. The decline in body weight coincided with a similar pattern in feed intake. Feed efficiency did not differ significantly among treatments, but the broilers exposed to the lowest concentration of ammonia showed the highest feed efficiency. Chickens exposed to the lowest ammonia concentrations regulated $\mathrm{T}_{\mathrm{b}}$ at significantly lower levels $\left(41.5^{\circ} \mathrm{C}\right.$ at $16 \mathrm{ppm}$ and $41.9^{\circ} \mathrm{C}$ at $\left.28 \mathrm{ppm}\right)$ than those at the highest concentrations $\left(42.3{ }^{\circ} \mathrm{C}\right.$ at 39 and $\left.54 \mathrm{ppm}\right)$. Arterial $\mathrm{pH}$ increased with increasing ammonia concentration and was similar in the upper 2 concentrations of ammonia. A similar but opposite trend was found in the partial pressure of arterial $\mathrm{CO}_{2}$. Plasma triiodothyronine $\left(\mathrm{T}_{3}\right)$ concentration did not differ significantly among treatments. It can be concluded that exposure to increased ammonia concentrations impairs broiler performance. It may also be suggested that ammonia can affect the ability of the chickens to control $\mathrm{T}_{\mathrm{b}}$ effectively.
\end{abstract}

ammonia / broiler / performance / body temperature / triiodothyronine

Résumé - L'ammoniac réduit les performances et affecte la thermorégulation des poulets de chair mâles. Les effets de différentes concentrations d'ammoniac dans l'air $(16 \pm 2 ; 28 \pm 3 ; 39 \pm$ 4 et $54 \pm 5 \mathrm{ppm})$ pour une température ambiante élevée $\left(\mathrm{T}_{\mathrm{a}}=32^{\circ} \mathrm{C}\right)$ et une hygrométrie de $60-65 \%$, ont été mesurés sur les performances et la thermorégulation des poulets de chair mâles. Le poids vif diminue significativement et proportionnellement aux concentrations croissantes d'ammoniac dans l'air. Cet effet coïncide avec les variations de l'ingéré alimentaire. L'efficacité alimentaire n'a pas été significativement différente d'un traitement à l'autre, mais les poulets exposés à la plus faible concentration d'ammoniac ont présenté la meilleure efficacité alimentaire. La température corporelle $\left(\mathrm{T}_{\mathrm{b}}\right)$ des poulets exposés aux plus faibles concentrations d'ammoniac a été régulée à un niveau plus bas $\left(41,5^{\circ} \mathrm{C}\right.$ à $16 \mathrm{ppm}$ et $41,9^{\circ} \mathrm{C}$ à $\left.28 \mathrm{ppm}\right)$ que celle des poulets élevés aux hautes concentrations d'ammoniac $\left(42,3^{\circ} \mathrm{C}\right.$ à 39 et $\left.54 \mathrm{ppm}\right)$. Le pH artériel a augmenté avec la concentration d'ammoniac dans l'air en restant similaire pour les deux doses les plus élevées. Une évolution opposée a été observée pour la pression partielle de $\mathrm{CO}_{2}$ artériel. La concentration plasmatique en triiodothyronine $\left(T_{3}\right)$ ne diffère pas significativement entre les traitements. On peut donc conclure que l'exposition à des concentrations croissantes d'ammoniac dans l'air réduit les performances des poulets.

${ }^{1}$ Contribution from the Agricultural Research Organization, the Volcani Center, Bet Dagan, Israel, No. 475/2004.

* Corresponding author: yahavs@agri.huji.ac.il 
L'ammoniac pourrait également affecter la capacité des poulets à contrôler efficacement leur température corporelle.

ammoniac / poulet de chair / performance / température corporelle / triiodothyronine

\section{INTRODUCTION}

The environment maintained in broiler houses has a major effect on the health and performance of broiler chickens. Ammonia gas, one of the poultry house products that are detrimental to broilers, is produced from uric acid and undigested proteins in manure, by aerobic or anaerobic bacteria $[4,8]$. The degradation of uric acid and undigested proteins into ammonia is influenced mainly by temperature, $\mathrm{pH}$ and the manure moisture content [3].

The deleterious effects of ammonia on weight gain, feed intake and feed conversion of broiler chickens have been reviewed by Carlile [1], Whyte [14] and Kristensen and Wathes [8]. However, chronic exposure to ammonia or previous experience with it may elicit a compensatory response to the pollutant and reduce its deleterious effect [6, 12].

Exposure to ammonia has been found to cause changes in the pulmonary ultrastructure that supports the mechanical defense mechanism of the respiratory system [10], and the respiratory system, especially the dead space, which plays a major role in the ability to control body temperature at high ambient temperatures, by panting [5, 17]. The effect of ammonia on the ability of broiler chickens to thermoregulate is not known.

The objectives of the present study were to determine the effects of acclimation to various concentrations of ammonia on the performance of male broiler chickens and on their ability to control body temperature.

\section{MATERIALS AND METHODS}

\subsection{Experimental procedure}

The study was conducted on fast-growing male Cobb chickens. All birds were obtained from a commercial hatchery and raised for 4 weeks in battery brooders under regular conditions [18]. At the age of 4 weeks, 192 chickens were selected by weight from a group of 240 birds. Birds with extreme weights were discarded. The birds were divided into 4 treatment groups, each including 8 replicates of 6 birds, with equal average body weights in all treatments and replicates. The birds were housed in cages -2 birds per cage - situated in 4 computer-controlled environmental chambers which maintained a constant temperature within $\pm 1.0^{\circ} \mathrm{C}$ and relative humidity (rh) within $\pm 2.5 \%$, under continuous fluorescent illumination. During the acclimation period (5th week), $\mathrm{T}_{\mathrm{a}}$, and $\mathrm{rh}$ were raised by equal increments to attain the target environmental conditions of the experiments: $32{ }^{\circ} \mathrm{C}$ and $60 \%$ rh (the optimal rh for raising broiler chickens at high $\mathrm{T}_{\mathrm{a}}$ [17]). The ammonia concentrations in the chambers were maintained at $16 \pm 2$, $28 \pm 3,39 \pm 4$ and $54 \pm 5 \mathrm{ppm}$, respectively, being controlled by the fresh air supply. The lower fresh air admission into the chambers allows maintaining the oxygen available for the chickens (taking into account the high volume of the chamber in comparison to that of the cages). Twice a day, the gas concentration was measured in different sites of the chamber with an Ammonia Electrolyte Sensor (Bionic Instrument, model TX2460FN-P with GS-2460DP). The diet was designed according to the National Research Council [9] recommendations, and water and feed in mash form were supplied ad libitum.

At weekly intervals, body weights and feed intake were recorded on individual and group bases, respectively between 4 and 7 weeks of age. Body temperature was measured with a digital thermometer (Sika TT-7170) in 10 birds of each treatment group. At 7 weeks of age, whole blood samples 
Table I. The effect of various ammonia concentrations in the air on the performance of male broiler chickens exposed to constant $32{ }^{\circ} \mathrm{C}$ and $60 \%$ relative humidity from the age of 4 to 7 weeks.

\begin{tabular}{lccccc}
\hline Variables & \multicolumn{3}{c}{ Ammonia concentration (ppm \pm SE) } & SEM \\
\cline { 2 - 5 } & $16 \pm 2$ & $28 \pm 3$ & $39 \pm 4$ & $54 \pm 5$ & 1 \\
\hline $\begin{array}{l}\text { Initial BW } \\
(4 \text { weeks, g) }\end{array}$ & 1056 & 1056 & 1059 & 1060 & 34 \\
$\begin{array}{l}\text { Final BW } \\
(7 \text { weeks, g) }\end{array}$ & $2119^{\mathrm{a}}$ & $2054^{\mathrm{ab}}$ & $1979^{\mathrm{bc}}$ & $1951^{\mathrm{c}}$ & 59 \\
$\begin{array}{l}\text { Feed intake } \\
\text { (g per 21 days) }\end{array}$ & $2114^{\mathrm{a}}$ & $2068^{\mathrm{ab}}$ & $1919^{\mathrm{bc}}$ & $1878^{\mathrm{c}}$ & \\
$\begin{array}{l}\text { FE } \\
\text { (g/g per 21 days) }\end{array}$ & 0.503 & 0.480 & 0.477 & 0.479 & 0.009 \\
\hline
\end{tabular}

Within rows, values designated by different letters differ significantly $(P \leq 0.05) ; \mathrm{n}=8$ replicates of 6 birds; BW: body weight; FE: feed efficiency.

were taken from the brachial vein, and were centrifuged at $1814 \mathrm{~g}$ for $10 \mathrm{~min}$ to obtain plasma, which was stored at $-20{ }^{\circ} \mathrm{C}$. Arterial blood samples $(2 \mathrm{~mL})$ were drawn from the brachial artery under anaerobic conditions, for immediate blood gas and $\mathrm{pH}$ analyses.

\subsection{Blood and plasma analysis}

$\mathrm{pH}$ and $p \mathrm{CO}_{2}$ were measured in arterial blood samples, with a Blood Micro System (Radiometer, Model BMS3 MK2). Radioimmunoassay for triiodothyronine $\left(\mathrm{T}_{3}\right)$ was performed in plasma samples, with commercial kits (Coat-A-Count, Canine, $\mathrm{T}$, kits - Diagnostic Products Corporation (DPC), Los Angeles, CA 90045-5597), validated for domestic fowl [15]. The $\mathrm{T}_{3}$ assay was characterized by intra-assay and inter-assay variation (cv) of 7.0 and $9.4 \%$, respectively.

\subsection{Statistical analysis}

In the experiment, there were 4 treatments (chambers) with different levels of ammonia. Each chamber contained 8 replicates of 6 birds. The results were averaged for each group of 6 birds ( 3 cages) and then subjected to analyses of variance (ANOVA) according to Snedecor and Cochran [13], and the Duncan multiple range test [2] was applied to them. The means were considered significantly different at $P \leq 0.05$.

\section{RESULTS AND DISCUSSION}

\subsection{Performance}

The effects of the different concentrations of ammonia in the air, on the performance of the male broiler chickens are summarized in Table I. The initial body weights (at 4 weeks of age) were similar in all treatments. Body weight declined significantly with increasing concentration of ammonia. At 7 weeks of age the decline in body weight paralleled a similar trend in feed intake. Feed efficiency did not differ among treatments, but the highest value was reached in broilers exposed to the lowest concentration of ammonia. The results in this study demonstrate a significant deleterious effect of aerial ammonia concentration on body weight gain and feed intake of broiler chickens, despite 3 weeks of chronic exposure to the pollutant. Other factors than ammonia (dust for instance) were unlikely to be involved in this deleterious effect because the air entering the chambers was filtrated, its velocity was very low $(0.25 \mathrm{~m}$ per second) and the chickens were housed 
Table II. The effects of various ammonia air concentrations on body temperature $\left(\mathrm{T}_{\mathrm{b}}\right)$, arterial $\mathrm{pH}$ and $p \mathrm{CO}_{2}$ and plasma triiodothyronine $\left(\mathrm{T}_{3}\right)$ concentrations.

\begin{tabular}{lccccc}
\hline Variables & \multicolumn{3}{c}{ Ammonia concentration $(\mathrm{ppm} \pm \mathrm{SE})$} & SEM \\
\cline { 2 - 4 } & $16 \pm 2$ & $28 \pm 3$ & $39 \pm 4$ & $54 \pm 5$ & \\
\hline $\mathrm{T}_{\mathrm{b}}\left({ }^{\circ} \mathrm{C}\right)$ & $41.50^{\mathrm{c}}$ & $41.91^{\mathrm{b}}$ & $42.27^{\mathrm{a}}$ & $42.26^{\mathrm{a}}$ & 0.18 \\
$\mathrm{pH}$ & $7.51^{\mathrm{b}}$ & $7.53^{\mathrm{ab}}$ & $7.56^{\mathrm{a}}$ & $7.56^{\mathrm{a}}$ & 0.02 \\
$p \mathrm{CO}_{2}(\mathrm{~mm} \mathrm{Hg})$ & $35^{\mathrm{a}}$ & $32^{\mathrm{ab}}$ & $29^{\mathrm{b}}$ & $29^{\mathrm{b}}$ & 1.43 \\
$\mathrm{~T}_{3}($ pg per $\mathrm{mL})$ & 0.757 & 0.856 & 0.900 & 1.041 & 0.115 \\
\hline
\end{tabular}

In rows, values designated by different letters differ significantly; $\mathrm{n}=10$ for $\mathrm{Tb}$ and 8 for blood analysis.

in cages. These results may, therefore, show that chronic exposure to ammonia does not elicit a complete compensatory response which would eliminate the deleterious effect on performance, as suggested by Reece et al. [12] and Johnson et al. [6]. However, reducing the ammonia concentration in the air, may lead to recovery of the chickens and may therefore evoke some growth compensation.

\subsection{Thermoregulation}

Body temperature was significantly affected by the concentration of ammonia in the air (Tab. II). The chickens exposed to the lowest ammonia concentrations regulated $T_{b}$ at significantly lower values than those exposed to the highest concentrations. Arterial $\mathrm{pH}$ increased with increasing ammonia concentration and was similar in the birds exposed to the 2 highest concentrations. An opposite trend was observed in the partial pressure of arterial $\mathrm{CO}_{2}$ (Tab. II). These results suggest a higher panting rate in broilers exposed to the higher concentrations of the pollutant $[17,18]$, but with lower efficacy to control $\mathrm{T}_{\mathrm{b}}$. Under the low ammonia concentrations, the broilers maintained $\mathrm{T}_{\mathrm{b}}$ within the known normothermic range for domestic fowl [11], whereas exposure to $39 \mathrm{ppm}$ of ammonia or more caused significant increases in $T_{b}$, which reached values typical of mild hyperthermia. In the present study, the air flow speed was $0.25 \mathrm{~m}$ per second, precluding the pos- sibility of losing heat by convection, and leaving panting as the main pathway for heat dissipation. It may be suggested, therefore, that changes in the pulmonary ultrastructure, resulting from the high aerial ammonia concentrations, could affect the efficiency of panting and hence the ability to control $\mathrm{T}_{\mathrm{b}}$ effectively under these environmental conditions.

Plasma $\mathrm{T}_{3}$ concentration did not differ significantly among treatments, but it was on average numerically the lowest in chickens exposed to the lowest ammonia concentration and higher with an increasing aerial ammonia concentration (Tab. II). Plasma $\mathrm{T}_{3}$ is the main metabolic hormone, and changes in its concentration have been found to be related to ambient temperature [16] and to feed intake in domestic fowls [7, $16,17,18]$. It can be speculated that a reduced $\mathrm{T}_{3}$ concentration in broilers exposed to the lowest aerial ammonia concentration might be associated with the relatively low energy demands imposed when the chickens are able to control $\mathrm{T}_{\mathrm{b}}$ efficiently. However, this hypothesis requires further confirmation.

It can be concluded that exposure to different atmospheric ammonia concentrations significantly impairs performance, to an extent which was found to be correlated with the pollutant concentration. It may also be suggested that ammonia can affect the ability to control $\mathrm{T}_{\mathrm{b}}$ effectively. For the practical point of view, it can be concluded that even under low aerial ammonia concentrations 
a significant effect on performance may appear, therefore, a proper ventilation of the poultry house is needed.

\section{ACKNOWLEDGMENT}

This study was supported by grant No. 3560360 from the Chief Scientist's Office of the Israeli Ministry of Agriculture and Rural Development, and by the Egg and Poultry Board of Israel grant No. 356-0350. The author wishes to thank Mr. M. Rusal and Dr. D. Shinder for technical assistance.

\section{REFERENCES}

[1] Carlile F.S., Ammonia in poultry houses: a literature review, World's Poult. Sci. J. 40 (1984) 99-113.

[2] Duncan D.B., Multiple range and multiple $F$ tests, Biometrics 11 (1955) 1-42.

[3] Elliot H.A., Collins N.E., Factors affecting ammonia release in broiler houses, Trans. ASAE 25 (1982) 413-424.

[4] Groot Koerkamp P.W.G., Review on emissions of ammonia from housing systems for laying hens in relation to sources, processes, building design and manure handling, J. Agric. Eng. Res. 59 (1994) 73-87.

[5] Hillman P.E., Scott N.R., van Tienhoven A., Physiological responses and adaptations to hot and cold environments, in: Yousef M.K. (Ed.), Stress Physiology in Livestock, Boca Raton, FL, CRC Press, Inc, Vol. 3, 1985, pp. 27-28.

[6] Johnson R.W., Curtis S.E., Shanks R.D., Effects on chick performance of ammonia and heat stressors in various combination sequences, Poult. Sci. 70 (1991) 1132-1137.
[7] Klandorf H., Harvey S., Feed intake regulation of circulating thyroid hormones in domestic fowl, Gen. Comp. Endocrinol. 60 (1985) 162-170.

[8] Kristensen H.H., Wathes C.M., Ammonia and poultry welfare: a review, World's Poult. Sci. J. 56 (2000) 235-245.

[9] National Research Council, Nutrient requirements of poultry, 9th ed., Washington, DC, National Academy of Science, 1994.

[10] Oyetunde O.O.F., Thomson R.G., Carlson H.C., Aerosol exposure of ammonia, dust and Escherichia coli in broiler chickens, Can. Vet. J. 19 (1978) 187-193.

[11] Prinzinger R., Pressmar A., Schleucher E., Body temperature in birds, Comp. Biochem. Physiol. A99 (1991) 499-506.

[12] Reece F.N., Lott B.D., Deaton J.W., Ammonia in the atmosphere during brooding affects performance of broiler chickens, Poult. Sci. 59 (1980) 486-488.

[13] Snedecor G.W., Cochran W.G., Statistical Methods, Ames, IA, Iowa State College Press, 1968.

[14] Whyte R.T., Aerial pollutants and the health of poultry farmers, World's Poult. Sci. J. 49 (1993) 139-156.

[15] Yahav S., Relative humidity at moderate ambient temperatures: its effect on male broiler chickens and turkeys, Brit. Poult. Sci. 41 (2000) 94-100.

[16] Yahav S., Domestic fowl - strategies to confront environmental conditions, Avian Poult. Biol. Rev. 11 (2000) 81-95.

[17] Yahav S., Goldfeld S., Plavnik I., Hurwitz S., Physiological responses of chickens and turkeys to relative humidity during exposure to high ambient temperature, J. Therm. Biol. 20 (1995) 245-253.

[18] Yahav S., Straschnow A., Plavnik I., Hurwitz S., Effect of diurnal cyclic versus constant temperatures on chicken growth and feed intake, Brit. Poult. Sci. 37 (1996) 43-54.

\section{To access this journal online: www.edpsciences.org}

